Economic Theory and the Developing Countries 


\section{Economic Theory and the Developing Countries}

\section{Ajit K. Dasgupta}

Senior Fellow,

Institute of Economic Growth, University of Delhi

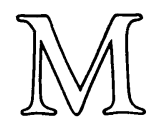


(C) Ajit K. Dasgupta 1974

All rights reserved. No part of this publication may be reproduced or transmitted, in any form or by any means, without permission.

First edition 1974

Reprinted 1977, 1978, 1979

ELBS edition first published 1980

Published by

THE MACMILLAN PRESS LTD

London and Basingstoke

Associated companies in Delhi Dublin

Hong Kong Johannesburg Lagos Melbourne

New York Singapore and Tokyo

ISBN 978-0-333-11299-1

ISBN 978-1-349-86195-8 (eBook)

DOI 10.1007/978-1-349-86195-8

This book is sold subject to the standard conditions of the Net Book Agreement.

The paperback editions of these books are sold subject to the condition that they shall not, by way of trade or otherwise, be lent, re-sold, hired out, or otherwise circulated without the publisher's prior consent in any form of binding or cover other than that in which they are published and without a similar condition including this condition being imposed on the subsequent purchaser. 


\section{Contents}

LIST OF TABLES viii

ACKNOWLEDGEMENTS ix

1 The Relevance of Economics 1

1.1 Introduction 1

1.2 Rationality and Underdevelopment 2

1.3 Technology: East and West 5

1.4 The Puritanical Ethic and Economic Development 7

$\begin{array}{lll}1.5 & \text { The Colonial Background } & 10\end{array}$

2 Dualism and Surplus Labour 14

2.1 The Dual Economy 14

2.2 An Unlimited Supply of Labour 15

2.3 Surplus Labour and Leisure Preference 16

2.4 Technological Under-employment 19

2.5 Surplus Labour due to Low Consumption 19

2.6 Tests of the Surplus Labour Hypothesis 20

2.7 Policy Implications 22

2.8 Conclusions $\quad 24$

3 The Population Problem 26

3.1 The Malthusian View 26

3.2 Economic Structure and the Population Problem 27

3.3 The Theory of Demographic Transition 28

3.4 Demographic Transition and the Developing
Countries

3.5 Population Planning 33

4 The Rate of Saving $\quad 35$

4.1 The Importance of Saving 35

4.2 Determinants of the Rate of Saving 37

4.3 The Absolute Income Hypothesis 37

4.4 The Life-Cycle Hypothesis 38

4.5 The Relative Income Hypothesis 38

4.6 The Permanent Income Hypothesis 39

4.7 Sectoral Savings Ratios $\quad 40$

4.8 Policy Implications $\quad 42$

4.9 Conclusions $\quad 43$ 
5 The Planning Problem: Optimum Investment

5.1 Planning and Capital Accumulation 45

5.2 The Theory of Optimum Growth 47

5.3 The Social Welfare Function 50

5.4 The Planning Horizon 53

5.5 Time Preference 56

5.6 Institutional Constraints 57

5.7 Conclusions 58

6 The Planning Problem: Investment AllocaTION AND the Choice of Techniques 59

6.1 Introduction

6.2 Investment Allocation and the Marketable Surplus Problem

6.3 The Choice of Techniques

6.4 Conclusions

62

66

7 InPut_Output Analysis $\quad 68$

7.1 Introduction 68

7.2 The Input-Output Table 68

7.3 Its Implication for Economic Structure 69

7.4 The Assumptions of Input-Output Analysis $\quad 70$

7.5 An Example $\quad 72$

7.6 Applications to Planning 73

7.7 The Dynamic Input-Output Model 75

$\begin{array}{lll}7.8 & \text { Criticisms } & 76\end{array}$

8 Linear Programming 79

8.1 The Assumptions of Linear Programming 79

8.2 An Example $\quad 80$

8.3 Some Difficulties $\quad 82$

$\begin{array}{lll}8.4 \text { Duality } & 83\end{array}$

8.5 Applications $\quad 85$

9 Cost-Benefit Analýsis $\quad 87$

9.1 Introduction 87

9.2 The Rationale of Cost-Benefit Analysis 87

9.3 Objectives $\quad 88$

9.4 Prices $\quad 89$

9.5 The Rate of Discount 93

9.6 Criticisms of Shadow Prices 94

9.7 Decision Criteria 95

10 Education and Manpower Planning 98 10.1 Introduction $\quad 98$

10.2 Cost-Benefit Analysis in Education 98 
Contents

vii

10.3 The Manpower Planning Approach 102

10.4 The Tinbergen-Correa Model 106

10.5 The Linear Programming Approach 107

10.6 Conclusions 108

11 Some International Aspects 110

11.1 International Trade and Economic Growth: Historical Arguments $\quad 110$

11.2 International Trade and Inequality 111

11.3 The Choice of Products for Exports and for Domestic Production

113

11.4 Policies for Trade Control

114

11.5 Foreign Aid

117

11.6 Concluding Remarks

119

REFERENCES

Notes on Further Reading 127

INDEX 


\section{Tables}

3.5.1 Decline in fertility in less developed countries

4.1.1 Frequency distribution of developing countries according to net national savings ratios, 1965-8

4.9.1 Frequency distribution of savings of households in developing countries, 1965-8

5.2.1 Investment ratios and economic growth

7.2.1 Transactions matrix

7.5.1 Matrix of input-output coefficients 


\section{Acknowledgements}

THIs book grew out of lectures to and discussions with my students at the University, Southampton; at Sir George Williams University, Montreal; and at the Institute of Economic Growth, Delhi. My greatest debt is to them.

Dr Sipra Dasgupta and Mr Raghav Gaiha went through the entire manuscript and made helpful criticisms. Miss Bina Aggarwal, $\mathrm{Mr}$ Ramesh Bhatia, Dr B. B. Bhattacharya, Dr P. C. Joshi, Dr Gopal Kadekodi, Dr Swapna Mukhopadhyaya, and Mr V. S. Ramachandra read parts of the book and suggested many improvements. Conversations with Dr Pranab Bardhan and Dr Sanjit Bose saved me from some errors. The co-operation and encouragement of Dr A. M. Khusro helped to keep this enterprise alive.

The book was partly written during the summer of 1973 , at the Institute of Advanced Studies, Simla. Thanks are due to them for providing a congenial environment in which to write.

Mr Shyam S. Sharma typed several versions of the manuscript with much patience. Mr S. C. Gupta provided research assistance. All errors that remain are mine alone. 